\title{
Antibiotic producing microorganisms from River Wiwi, Lake Bosomtwe and the Gulf of Guinea at Doakor Sea Beach, Ghana
}

\author{
Adelaide A Tawiah', Stephen Y Gbedema ${ }^{1 *}$, Francis Adu ${ }^{1}$, Vivian E Boamah ${ }^{1}$ and Kofi Annan ${ }^{2}$
}

\begin{abstract}
Background: Microorganisms have provided a wealth of metabolites with interesting activities such as antimicrobial, antiviral and anticancer. In this study, a total of 119 aquatic microbial isolates from 30 samples (taken from water bodies in Ghana) were screened by the agar-well diffusion method for ability to produce antibacterial-metabolites.
\end{abstract}

Results: Antibacterial activity was exhibited by 27 of the isolates (14 bacteria, 9 actinomycetes and 4 fungi) against at least one of the indicator microorganisms: Enterococcus faecalis (ATCC 29212), Bacillus thuringiensis (ATCC 13838), Pseudomonas aeruginosa (ATCC 27853), Staphylococcus aureus (ATCC 25923), Proteus vulgaris (NCTC 4635) and Bacillus Subtilis (NCTC 10073). A sea isolate MAI2 (identified as a strain of Pseudomonas aeruginosa) exhibited the highest antibacterial activity (lowest zone of inhibition $=22 \mathrm{~mm}$ ). The metabolites of MAl2 extracted with chloroform were stable to heat and gave minimum inhibitory concentrations ranging between 250 and $2000 \mathrm{\mu g} / \mathrm{ml}$. Bioautography of the extract revealed seven active components.

Conclusion: This study has therefore uncovered the potential of water bodies in the West African sub-region as reservoirs of potent bioactive metabolite producing microorganisms.

Keywords: Aquatic microorganisms, Antibiotics, Ghana, Multi-drug resistance

\section{Background}

Throughout the ages, natural products have been the most consistently successful source of lead compounds that have found many applications in the fields of medicine, pharmacy and agriculture. Microbial natural products have been the source of most of the antibiotics in current use for the treatment of various infectious diseases. Since the discovery of penicillin in 1928, studies on soil bacteria and fungi have shown that microorganisms are a rich source of structurally unique bioactive substances [1]. After Penicillin, many other drugs including chlortetracycline, chloramphenicol, streptomycin, erythromycin, rifamycin, lincomycin, cephalosporin C, vancomycin, erythromycin, nalidixic acid, amphotericin $\mathrm{B}$, nystatin, and daunorubicin the antitumor agent were

\footnotetext{
* Correspondence: sgbedema.pharm@knust.edu.gh

'Department of Pharmaceutics, Faculty of Pharmacy and Pharmaceutical Sciences, College of Health Sciences, Kwame Nkrumah University of Science and technology, Kumasi, Ghana

Full list of author information is available at the end of the article
}

discovered from microorganisms. Currently, many of the pathogens implicated in infectious disease are rapidly developing resistance to the available antibiotics [2] making treatment of these infections very difficult [3], hence the need to look for more effective antibiotics.

Until recently, majority of antimicrobial compounds were isolated from terrestrial microorganisms. In the last two decades however, the rate of discovery of novel compounds from this source has significantly declined, as exemplified by the fact that extracts from soil-derived actinomycetes have yielded high numbers of clinically unacceptable metabolites [4]. The aquatic environment is now becoming increasingly appreciated as a rich and untapped reservoir of useful novel natural products. The marine environment alone is known to contain taxonomically diverse bacterial groups which exhibit unique physiological and structural characteristics that enable them to survive in extreme environmental conditions, with the potential production of novel secondary metabolites not observed in terrestrial microorganisms [5]. 
Several compounds including pestalone, hypoxysordarin and equisetin, isolated from sea microorganisms have shown promising antibacterial, antifungal and antiviral activities respectively. Salinosporamide A isolated from marine Salinispora tropica, has been shown to exhibit both anticancer and antimalarial activities and is currently undergoing clinical trial [6].

In Ghana and other sub-Saharan African countries is a diverse array of aquatic habitats. These water bodies are reservoirs of enormous biological diversity which have not been exploited for bioactive natural products. In this study therefore, we report the presence of potent antimicrobial metabolite producing microorganisms in some aquatic habitats in Ghana.

\section{Methods}

\section{Sampling and Isolation of microorganisms}

The Gulf of Guinea at Cape Coast Duakor Sea beach and two fresh water bodies in the Ashanti region of Ghana; Lake Bosomtwe and River Wiwi, were selected for this study. Thirty samples of water, weeds, stones and sediments were collected from each of these sites and transported at $4^{\circ} \mathrm{C}$ to the laboratory. Water samples were collected by submerging sterile $1 \mathrm{~L}$ glass bottles in the water to a depth of about $10 \mathrm{~cm}$ and then opened to fill after which they were closed and brought to surface. About five grams (5 g) each of sediment materials, stones and weed in the water bodies were collected into bottles.

All samples were processed within 12 hours of collection. About $1 \mathrm{ml}$ quantities of the water samples were separately inoculated into $20 \mathrm{ml}$ molten Nutrient agars and Sabouraud agars (Merck, Nottingham, UK). The stones and weed samples were gently and separately scrubbed with sterile brush into $10 \mathrm{ml}$ sterile normal saline and $1 \mathrm{ml}$ quantities were added to the molten agars. About $1 \mathrm{~g}$ of the soil samples were also suspended in $5 \mathrm{ml}$ of normal saline and $1 \mathrm{ml}$ of these suspensions were added to the agars. All the plates were incubated (Nutrient agars at $37^{\circ} \mathrm{C}$ and Sabouraud agars at $25^{\circ} \mathrm{C}$ ) for seven days with daily observation. Colonies that appeared to have clear zones around them were carefully isolated into pure cultures.

\section{Test microorganisms}

These microorganisms from the stocks kept by the Microbiology Laboratory of the Department of Pharmaceutics were used in the study: Bacillus thuringiensis (ATCC 13838), Staphylococcus aureus (ATCC 25923), Bacillus subtilis (NCTC 10073), Pseudomonas aeruginosa (ATCC 27853), Proteus vulgaris (NCTC 4175), Enterococcus faecalis (ATCC 29212), Escherichia coli (clinical isolate), Salmonella typhi (clinical isolate) and Candida albicans (clinical isolate).

\section{Screening of isolated microorganisms for inhibitory activity}

The isolates were screened for antibacterial metabolite production using the agar-well diffusion method. The inocula were prepared by growing the various test organisms on separate agar plates and colonies from the plate were transferred with inoculating loop into $3 \mathrm{ml}$ of normal saline in a test tube. The density of these suspensions was adjusted to 0.5 McFarland standards. The surface of Muller-Hinton agar (Oxoid Cambridge, UK) plate was evenly inoculated with the test organisms using a sterile swab: the swab was dipped into the suspension and pressed against the side of the test tube to remove excess fluid. The wet swab was then used to inoculate the Muller-Hinton agar by evenly streaking across the surface. By means of a sterile cork borer wells ( $8 \mathrm{~mm}$ in diameter) were made in the agar and filled with $0.2 \mathrm{ml}$ of $72 \mathrm{~h}$ culture of the isolate microorganism. Two replicates of the experiment were done and the plates incubated at $37^{\circ} \mathrm{C}$ for $18 \mathrm{~h}$. The diameters of zone of growth-inhibition produced were measured and the mean values calculated (Table 1). Isolates MAI1, MAI2 and MAI3 produced the highest zones and were therefore selected for the next level of studies.

\section{Testing thermal stability of antibacterial metabolites of selected isolates}

About $1 \mathrm{ml}$ of the broth cultures of isolates MAI1, MAI2 and MAI3 were separately inoculated into $10 \mathrm{ml}$ nutrient broths and incubated at $37^{\circ} \mathrm{C}$ for 72 hours. They were then centrifuged at $6000 \mathrm{rpm}$ for one hour to precipitate the microbial cells from the metabolite solutions. The resulting supernatants were decanted and filtered through Whatman (No. 1) filter paper into clean sterile test tubes in $1 \mathrm{ml}$ quantities and exposed to various temperatures from 40 to $121^{\circ} \mathrm{C}$ for $15 \mathrm{~min}$. They were then re-tested for antimicrobial activity against $B$. subtilis. The metabolites of MAI2 showed better stability and hence was finally selected for further studies.

\section{Effect of growth factors on antibacterial activity of MAI2 metabolites \\ Incubation period}

The incubation period for maximum activity of MAI2 was assessed by fermenting it in $250 \mathrm{ml}$ of nutrient broth in a shaking incubator at $37^{\circ} \mathrm{C}$. Aliquots of $10 \mathrm{ml}$ of the culture were withdrawn at $24 \mathrm{~h}$ intervals and centrifuged as above. The cell-free supernatant was assayed for inhibitory activity against $B$. subtilis.

$p H$ : The optimum $\mathrm{pH}$ for maximum activity was assessed by fermenting MAI2 in tubes of $10 \mathrm{ml}$ nutrient broth at varying $\mathrm{pHs}(4,5,6,7,8$ and 9) after which their antibacterial activity was evaluated by the cup plate method as above. 
Table 1 Antimicrobial activity of isolates against the test microorganisms employed

\begin{tabular}{|c|c|c|c|c|c|c|c|}
\hline \multirow[t]{2}{*}{ Producers } & & \multicolumn{6}{|c|}{ Mean zones of growth-inhibition $(\mathrm{mm})$ of test organisms ( \pm SEM) } \\
\hline & & PA & BT & BS & EF & SA & PV \\
\hline SAI 19 & Ac & $14 \pm 1.12$ & $16 \pm 0.11$ & $15 \pm 0.41$ & $11 \pm 0.21$ & $14 \pm 2.0$ & $15 \pm 0.21$ \\
\hline SAI 22 & Ac & - & - & $11 \pm 3.05$ & $14 \pm 2.22$ & $11 \pm 0.07$ & $12 \pm 1.20$ \\
\hline SAI 20 & $\mathrm{Br}$ & - & $11 \pm 0.66$ & - & $11 \pm 0.02$ & - & $13 \pm 0.10$ \\
\hline SAI 28 & $\mathrm{Br}$ & - & $12 \pm 2.12$ & - & $13 \pm 0.01$ & - & $11 \pm 2.07$ \\
\hline SAI 29 & $A C$ & - & $14 \pm 0.31$ & $13 \pm 0.77$ & $14 \pm 0.73$ & - & - \\
\hline SAI 18 & $\mathrm{Br}$ & - & $12 \pm 1.11$ & - & $12 \pm 1.27$ & - & $12 \pm 1.16$ \\
\hline SAI 9 & $\mathrm{Br}$ & - & $10 \pm 1.54$ & - & - & - & - \\
\hline SAI 12 & $\mathrm{Br}$ & - & $12 \pm 0.97$ & - & - & - & $12 \pm 0.16$ \\
\hline SAI 36 & $A C$ & - & $13 \pm 0.76$ & $13 \pm 0.76$ & $14 \pm 0.46$ & $14 \pm 1.17$ & $12 \pm 0.55$ \\
\hline SAI 31 & $A C$ & - & $12 \pm 3.27$ & - & $11 \pm 3.09$ & - & - \\
\hline SAI 32 & $\mathrm{Fg}$ & - & $12 \pm 0.09$ & $11 \pm 0.83$ & $12 \pm 2.39$ & $13 \pm 0.09$ & $12 \pm 1.43$ \\
\hline SAI 35 & $\mathrm{Br}$ & - & $14 \pm 0.04$ & $14 \pm 0.98$ & $14 \pm 4.01$ & $12 \pm 2.17$ & $12 \pm 2.44$ \\
\hline SAI 23 & $\mathrm{Br}$ & - & - & - & - & - & $12 \pm 0.26$ \\
\hline SAI 5 & $\mathrm{Fg}$ & - & - & $11 \pm 0.45$ & - & - & $11 \pm 0.15$ \\
\hline WEI 3 & $A C$ & - & $14 \pm 1.22$ & $14 \pm 0.11$ & $15 \pm 1.44$ & $15 \pm 0.11$ & $13 \pm 0.03$ \\
\hline WEI 7 & $\mathrm{Br}$ & - & $11 \pm 4.11$ & - & $12 \pm 0.33$ & $12 \pm 0.43$ & - \\
\hline WEI 13 & $\mathrm{Fg}$ & - & $11 \pm 0.23$ & - & $13 \pm 0.76$ & - & $11 \pm 3.27$ \\
\hline WEI 14 & $A C$ & - & $14 \pm 2.91$ & $13 \pm 3.23$ & $16 \pm 1.28$ & $13 \pm 4.30$ & $13 \pm 1.30$ \\
\hline WEI 16 & $\mathrm{Br}$ & - & - & - & $11 \pm 2.99$ & - & - \\
\hline WEI 19 & $\mathrm{Br}$ & - & - & - & $10 \pm 1.19$ & - & - \\
\hline BS 1 & $A C$ & $13 \pm 4.09$ & $14 \pm 5.10$ & $15 \pm 1.22$ & $12 \pm 0.61$ & $13 \pm 2.99$ & $14 \pm 0.91$ \\
\hline BS 8 & $\mathrm{Br}$ & - & - & - & - & - & $17 \pm 2.07$ \\
\hline BS 26 & $\mathrm{Fg}$ & - & - & $13 \pm 0.22$ & $15 \pm 0.09$ & - & - \\
\hline MAI 1 & $\mathrm{Br}$ & - & $20 \pm 0.11$ & $17 \pm 0.26$ & $22 \pm 1.40$ & $20 \pm 0.18$ & $17 \pm 0.99$ \\
\hline MAI 2 & $\mathrm{Br}$ & - & $24 \pm 1.16$ & $26 \pm 2.33$ & $22 \pm 2.14$ & - & $25 \pm 3.17$ \\
\hline MAI 3 & $\mathrm{Br}$ & - & - & $20 \pm 2.19$ & $22 \pm 0.49$ & - & - \\
\hline MAI 4 & $A C$ & - & - & - & $15 \pm 0.87$ & - & - \\
\hline
\end{tabular}

Key: $A c=$ Actinomycetes, $B r=$ Bacteria, $F g=$ fungi, $P A=P$. aeruginosa, $E F=E$. faecalis, $B T=B$. thuringensis, $S A=S t a p h$ aureus, $B S=B$. Subtilis, $P V=P r$. vulgaris. $S A I=$ Sand isolates from River Wiwi, $W E I=$ weed isolates from River Wiwi, $M A I=$ marine isolates, $B S=$ isolates from Lake Bosomtwe.

\section{Carbon and nitrogen sources}

The source of carbon for optimum activity was assessed by cultivating the isolate in $10 \mathrm{ml}$ fermentation media fortified with $60 \mathrm{mg}$ of various carbon sources: glucose, galactose, xylose, sucrose, mannitol, lactose, starch, fructose, maltose and glycerol. The metabolite solutions obtained were tested for antimicrobial activity against $B$. subtilis. The procedure was repeated for nitrogen sources (asparagine, sodium nitrate, potassium nitrate, ammonium chloride, ammonium nitrate, ammonium phosphate and ammonium sulphate).

\section{Extraction of metabolites of Isolate MAI2}

The isolate was inoculated into $2.5 \mathrm{~L}$ of nutrient broth and incubated at $37^{\circ} \mathrm{C}$ for 10 days. The culture was then centrifuged at $6000 \mathrm{rpm}$ for $1 \mathrm{~h}$ and the supernatant filtered, extracted with chloroform and dried at room temperature $\left(25^{\circ} \mathrm{C}\right)$. Two replicates were done and the extracts obtained were weighed and kept in a desiccator for use.

\section{Minimum inhibitory and bactericidal concentrations determination of MAI2 extract}

Minimum Inhibitory Concentration (MIC) was determined using the broth dilution method. Serial dilutions $(100 \mu \mathrm{l})$ of the extract in Mueller-Hinton Broth (SigmaAldrich, St. Louis, MO, USA) in the range of $62.5 \mu \mathrm{g} / \mathrm{ml}$ to $4000 \mu \mathrm{g} / \mathrm{ml}$ were made in 96 -well micro-plates. The inocula $(100 \mu \mathrm{l})$ of the test microorganisms prepared from $18 \mathrm{~h}$ broth cultures (containing $10^{5} \mathrm{cfu} / \mathrm{ml}$ ) were dispensed into the plates. Three replicates were made. The plates were incubated at $37^{\circ} \mathrm{C}$ for 24 hours. Bacterial growth was determined after addition of $20 \mu \mathrm{l}$ of $0.2 \mathrm{mg} / \mathrm{ml}$ MTT (Sigma-Aldrich, St. Louis, MO, USA). 


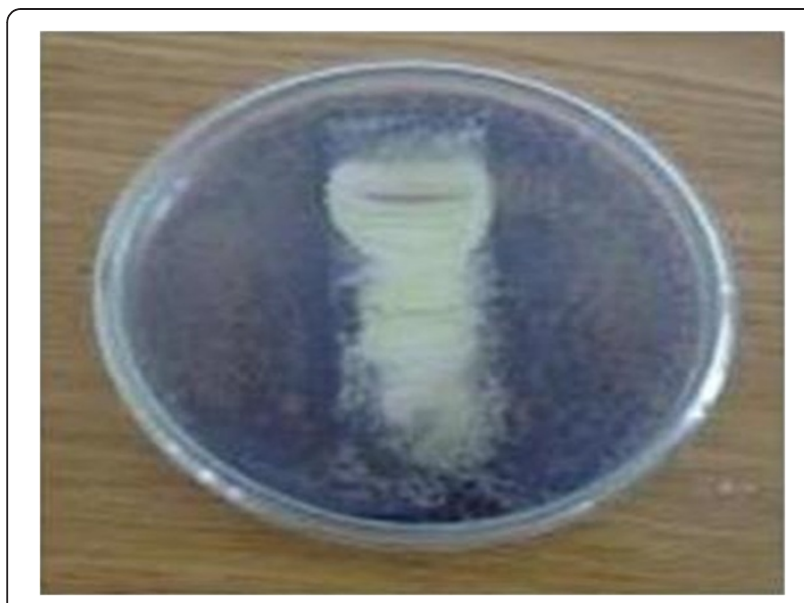

Figure 1 Bioautography of MAI2 extract against Pr.vulgaris.

The minimum bactericidal concentration (MBC) test was performed as above in the MIC determination except that $100 \mu \mathrm{l}$ aliquots were withdrawn from wells that showed inhibition in the MIC experiment and inoculated into $5 \mathrm{ml}$ nutrient broths. These were incubated at $37^{\circ} \mathrm{C}$ for 5 days and observed for signs of growth.

\section{Bioautography assay}

Bioautography as described by Nostro et al. [7] was performed using Pr. vulgaris which showed a good sensitivity to the crude extracts. Briefly, developed and dried Silica gel 60 microns TLC plates (Merck, Nottingham, UK) were overlaid with agar seeded with an overnight culture of $\mathrm{Pr}$. vulgaris. The plates were incubated for $24 \mathrm{~h}$ at $37^{\circ} \mathrm{C}$ and then sprayed with an aqueous solution of $2 \mathrm{mg} / \mathrm{ml} \mathrm{MTT}$. Zones of growth inhibition appeared clear against a purple background (Figure 1).

\section{Characterization of isolate MAI2}

The morphological features of the colonies including sizes, shapes, colour and pigmentation and microscopic features of the cells in addition to biochemical tests such as growth on cetrimide agar, indole and oxidase production, citrate utilization, starch hydrolysis and carbohydrate fermentations were used to characterize isolate MAI2 in accordance with Barrow and Felthan [8]. Pseudomonas aeruginosa (ATCC 27853) was employed as the reference organism. The other 26 active isolates were as well identified and classified as bacteria, actinomycetes or fungi.

\section{Results}

Isolation, antibacterial activity and thermal stability

A total of 119 isolates suspected of having the capability to produce inhibitory metabolites were recovered from the 30 samples collected, out of which 27 (23\%) (made up of 14 bacteria, 9 actinomycetes and 4 fungi) actually exhibited antimicrobial properties (determined by zone of growth inhibition $\geq 10 \mathrm{~mm}$ ) against at least one of the test bacteria used (Figure 2; Table 1). 66.7\% of the strains inhibited B. thuringiensis, 60\% inhibited B. subtilis, 37\% inhibited Staph. aureus, 66.7\% inhibited Pr. vulgaris and 81.48\% inhibited Ent. faecalis. Only two of the isolates inhibited $P$. aeruginosa. Three of the bacterial isolates (MAI1, MAI2 and MAI3) produced inhibition zones greater than $19 \mathrm{~mm}$ but their antibacterial activity was lost on exposure to temperatures beyond $60^{\circ} \mathrm{C}$ except MAI2 which maintained activity up to $100^{\circ} \mathrm{C}$. As such MAI2 was selected for further evaluation of its antibiotic and also identified to be a strain of P. aeruginosa.

There was an increase in the antibacterial activity of MAI2 metabolites up to the ninth day of incubation after which there was no significant increase $(\mathrm{p}<0.005$; Figure 3). The optimum $\mathrm{pH}$ for maximum antibacterial activity of MAI2 was determined to be 7 and no activity was observed at $\mathrm{pH}$ of 4 (Figure 4). Fortification of the fermentation medium with glycerol produced the highest activity followed by starch as carbon sources (Figure 5) while asparagine gave the highest activity in the case of nitrogen sources (Figure 6). The effects of all the other carbon and nitrogen sources were either

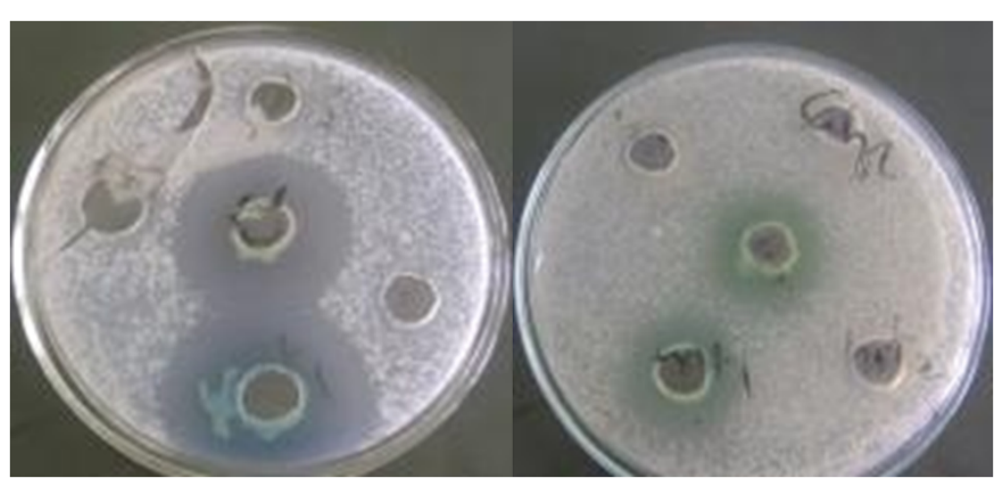

Figure 2 Samples of the agar plates showing zones of growth inhibition. 


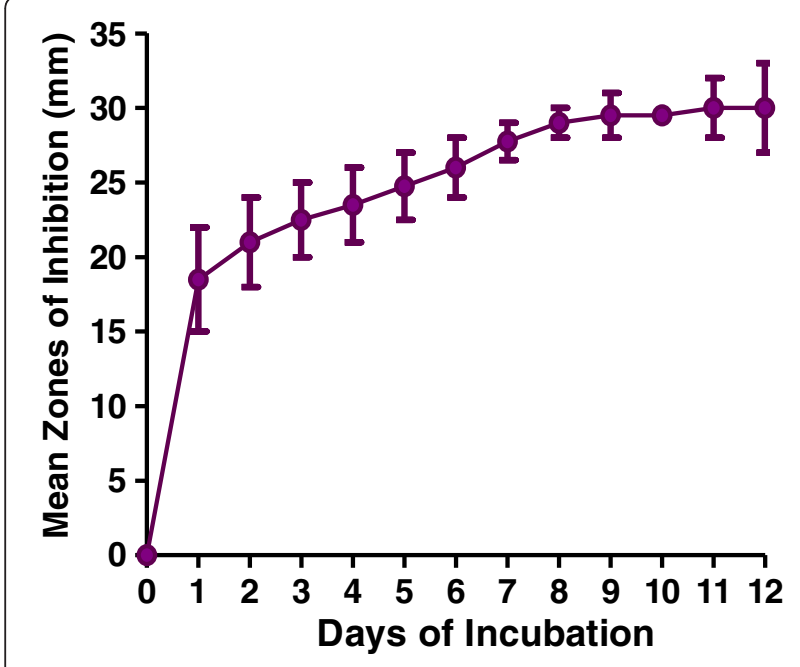

Figure 3 Incubation period and antibacterial activity of MAI2 against $B$. Subtilis.

equal or significantly lower than the control (nutrient broth).

\section{Extraction and antimicrobial activity of crude extract}

The crude extract obtained $(0.281 \mathrm{~g}$ per $2.5 \mathrm{~L}$ fermentation medium) was dark brown in colour and exhibited activity against E. coli, Pr. vulgaris, Ent. faecalis, Staph. aureus, B. subtilis, B. thuringiensis, S. typhi and C. albicans with MIC values ranging between 250 to $2000 \mu \mathrm{g} / \mathrm{ml}$ (Table 2). Growth was however observed in all the tubes in the MBC determination at the concentrations tested.

\section{TLC analysis}

TLC of the crude extract showed 7 components under UV light at $254 \mathrm{~nm}$ and the $\mathrm{R}_{\mathrm{f}}$ values of the spots are $0.86,0.77,0.55,0.52,0.44,0.30$ and 0.22 in chloroform-

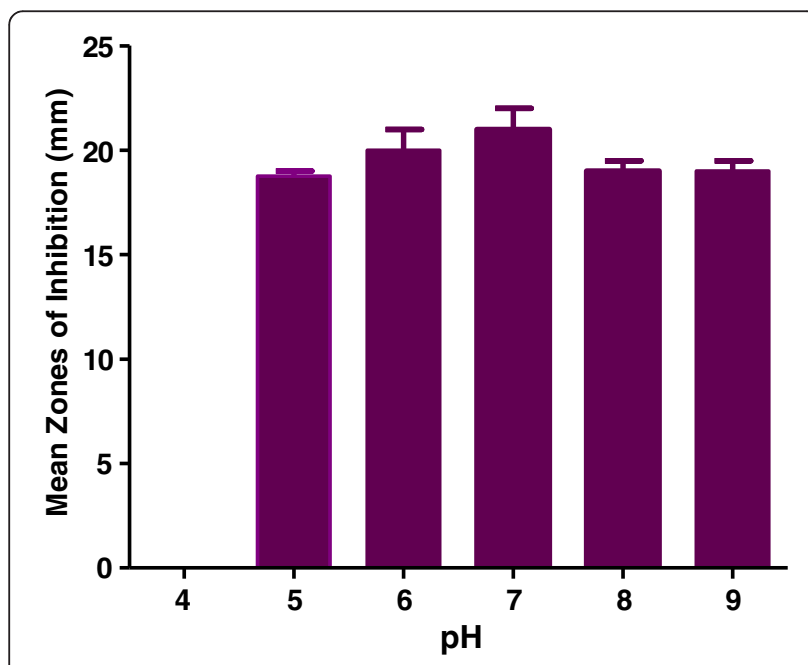

Figure 4 Effect of pH on antibacterial activity of Isolate MAI2. ethyl acetate (3.5:1.5) solvent system. All the components appeared to have exhibited antibacterial activity (Figure 1).

\section{Discussion}

New and effective antibiotics are crucial in this current surge of multi-drug resistant bacterial infections which have rendered many of the currently available antibiotics useless. Natural products have served and continue to provide useful lead compounds for development into chemotherapeutic agents. Aquatic microorganisms have emerged as a source of diverse chemical compounds which have not been adequately studied for chemotherapeutic application. Our results have revealed 27 (23\%) antibiotic producing microorganism out of 119 isolates recovered from both marine and fresh water sources in Ghana and this is the first report of this kind of study in the West African sub-region. Many reports have been made of such studies elsewhere. For example Ivanova et al. [9] reported that out of the 491 bacteria isolated from different marine sources, $26 \%$ of the isolates were active. Zheng et al. [10] also reported that 8 out of 29 strains, representing $28 \%$ of the isolates considered in their study produced antimicrobial activity against at least one of their test microorganisms. Brandelli et al. [11] also recorded $70 \%$ of active isolates from the Amazon Basin whilst O'Brien et al. [12] recorded as low as $0.29 \%$ (13 out of 4496) of active microbes from soil samples collected at different location in the Antarctica.

The comparatively high number of antibiotic producers recorded in our study can be partly attributed to the nature of our water bodies: they are usually highly polluted with all kinds of waste materials; from domestic and industrial wastewater discharges, mining runoff, agro-chemicals and other sources [13-16] and river wiwi, Lake Bosomtwe and the Gulf of Guinea at Duakor Sea Beach where the samples were collected are no exceptions. To survive and maintain their niche under these harsh conditions therefore, the aquatic microorganisms need defense mechanisms and for some, antimicrobially active metabolite production could be one of such mechanisms. The differences among the detection rates reported in literature strongly depend on the isolation and assay procedures, test organisms, type of media used, as well as the sources of bacterial isolates [17]. In our study, only those isolates producing extracellular antibiotics were detected, hence very huge numbers could be recorded if our procedures include microorganisms producing intracellular antibiotics since they will only secrete their antibiotics into media in the presence of competition, to antagonise other organisms for survival [18].

Isolate MAI2 which was identified as a strain of Pseudomonas aeruginosa, exhibited the highest antibacterial 


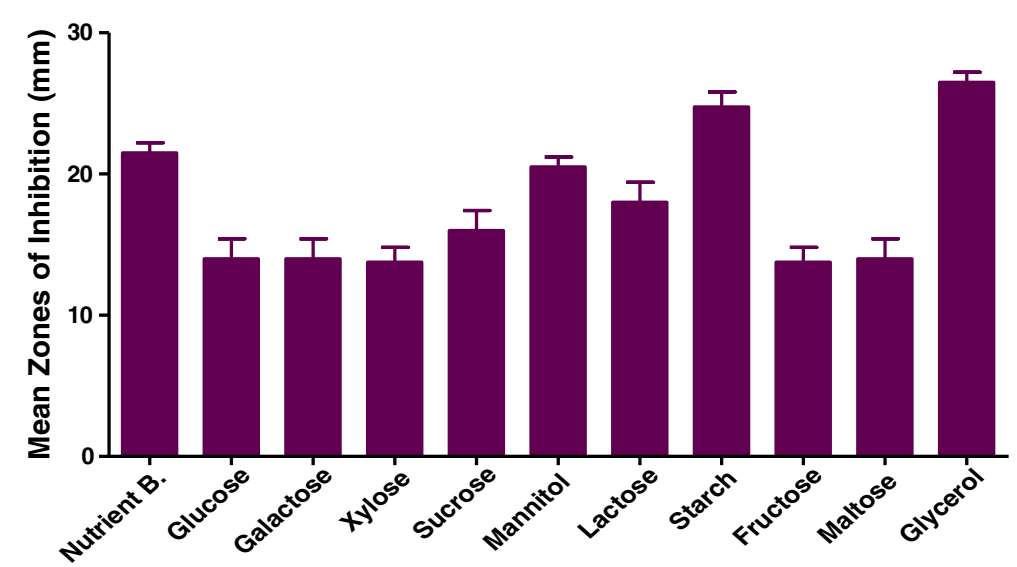

Figure 5 Effect of carbon sources on antimicrobial activity of MAI2 against $B$. subtilis.

activity and produced perhaps, moderately thermostable antibacterial metabolites, shown by exhibition of antibacterial activity when the metabolites solution was exposed to temperatures up to $100^{\circ} \mathrm{C}$ but destroyed at $121^{\circ} \mathrm{C}$ for $15 \mathrm{~min}$. This result is in contrast to those reported by Preetha et al. [19] who reported that the antimicrobial agent produced by Pseudomonas species MCCB was stable after autoclaving at $121^{\circ} \mathrm{C}$ for $20 \mathrm{~min}$ even though there was a significant reduction in activity. Uzair et al. [20] also reported the thermal stability of an antimicrobial agent produced by Pseudomonas aeruginosa at a temperature of $121^{\circ} \mathrm{C}$ for 20 minutes. However, Roitman et al. [21] showed that variations in the fermentation medium often results in changes in the composition of the antibiotics produced. The differences in the thermal stability of the antimicrobial agents produced in this study as compared to other studies may therefore be due to differences in some nutritional and or physical factors which led to the production of metabolites that are thermolabile at temperatures beyond $100^{\circ} \mathrm{C}$.

Our results also showed that nine days incubation period was optimum for maximum antibacterial activity by MAI2, an indication of maximum antibiotic production, after which there was no significant increase. Several other factors influence production of secondary metabolites by microorganisms, the most important one being the composition of the fermentation medium [22]. Sole et al. [23] noted that glucose can be used as a source for bacterial growth while repressing the production of secondary metabolites. The isolate (MAI2) utilised glycerol and starch best for maximum production of the antimicrobial metabolites.

Nitrogen is very vital in the synthesis of enzymes involved in primary and secondary metabolism [24]. Therefore depending on the biosynthetic pathways involved, nitrogen

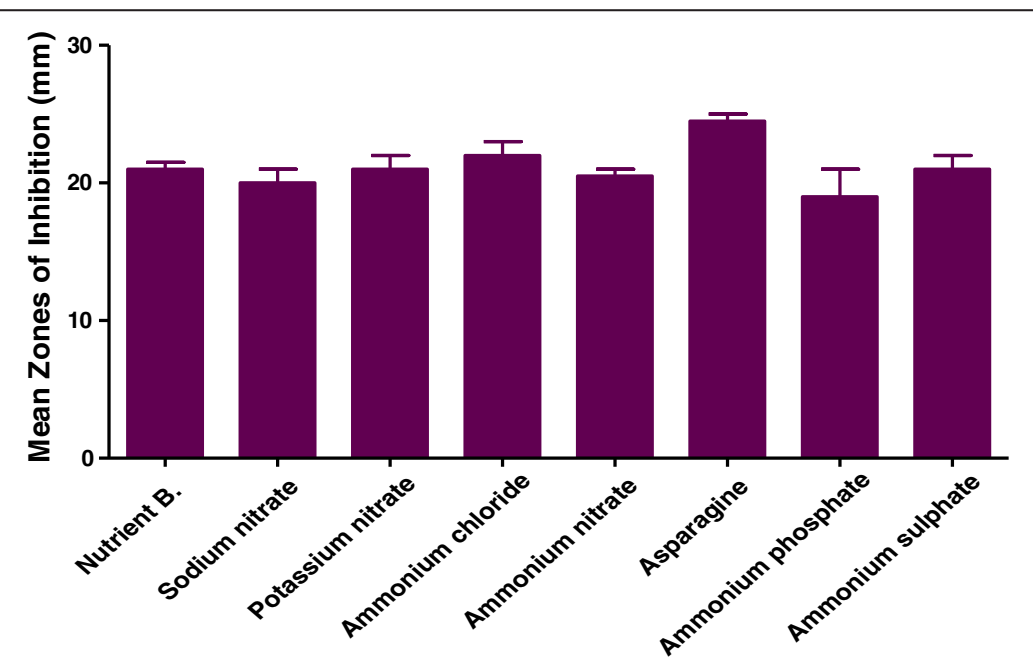

Figure 6 Effect of nitrogen sources on antibacterial activity of MAI2 against B. Subtilis. 
Table 2 MIC of the crude extract of MAI2

\begin{tabular}{lc}
\hline Test organism & MIC in $\boldsymbol{\mu g} \mathbf{m l}$ \\
\hline E. coli & 500 \\
Pr. vulgaris & 250 \\
Ent. Faecalis & 500 \\
Staph. aureus & 1000 \\
B. subtilis & 250 \\
B. thuringiensis & 1000 \\
S. typhi & 500 \\
C. albicans & 2000 \\
\hline
\end{tabular}

sources may affect antibiotic formation. Shapiro [25] noted that the type of nitrogen source (organic or inorganic) plays a role in the synthesis of secondary metabolites. Charyulu and Gnanamani [26] reported that Pseudomonas aeruginosa MTCC 5210 utilized organic nitrogen source for better yield of antimicrobial metabolites than the inorganic sources. These observations are consistent with the findings of this study as asparagine was better used for antibiotic production by MAI2 than the inorganic nitrogen sources (sodium and potassium nitrates and the ammonium salts) employed.

Generally, the intracellular $\mathrm{pH}$ of most microorganisms is maintained near neutrality regardless of the $\mathrm{pH}$ in the outside medium [27]. However as the proton gradient across the cytoplasmic membrane increases, the cells commit more of their resources towards maintaining the desired intracellular $\mathrm{pH}$ [28], thus changes in external $\mathrm{pH}$ affect many cellular processes such as growth and the regulation of the biosynthesis of secondary metabolites [29]. The highest activity of the antimicrobial metabolite by the strain was at $\mathrm{pH} 7$. This result agrees with a study carried out by Charyulu and Gnanamani [26] who reported maximum production of metabolite by Pseudomonas aeruginosa MTCC 5210 at $\mathrm{pH} 7$.

Isolate MAI2 exhibited antimicrobial activity against both gram-positive and gram-negative microorganisms as well as C. albicans, indicating that the metabolites have a broad antimicrobial spectrum.

The seven components observed in the TLC analysis of the extract points to the fact that organisms can produce more than one antimicrobial agent to provide themselves with survival competition superiority. Further work is ongoing in our laboratory to isolate and test the various components of the extract. It is hoped that these components when isolated into pure constituents can serve as leads for the development of novel and potent antibiotics as well as resistant reversing compounds $[30,31]$ which may be useful in combination therapies as exemplified by clavulanic acid in Augmentin ${ }^{\mathrm{R}}$ (GlaxoSmithKline).
The extract is bacteriostatic in its mode of action since there were revivable cells of the test organisms in the wells in which inhibition was observed. Bacteriostatic agents like the $\beta$ - lactams have been of great value in the treatment of bacterial infections including endocarditis, meningitis, and osteomyelitis [32]. Other bacteriostatic agents such as the lincosamides (example clindamycin) have been shown to completely inhibit the toxic shock syndrome toxin-1 production by Staph. aureus [33] and toxin production in both streptococci and staphylococci [34]. These reports suggest that the active constituents MAI2 crude extract have the potential of being efficacious in the treatment of various infections.

\section{Conclusions}

It was found out from this study that antibiotic producing microorganisms are present in Lake Bosomtwe, river wiwi at KNUST campus and the Gulf of Guinea at Duakor Sea beach. Out of the 119 isolates recovered, 27 produced antibacterial metabolites against at least one of the test organisms. The crude metabolite extract of isolate MAI2 (a strain of $P$. aeruginosa) was active against all the test organisms; $B$. thuringiensis, Pr. vulgaris, Ent. faecalis, Staph. aureus, B. subtilis, E. coli, S. typhi and C. albicans with MICs ranging between 250 and $2000 \mu \mathrm{g} / \mathrm{ml}$.

\section{Competing interests}

The authors declare that they have no competing interest.

\section{Authors' contributions}

SYG conceived and designed the experimental plan, AAT performed most of the experiments, FA and KA performed chromatographic analysis, SYG, AAT and VEB analysed data and wrote the manuscript; all authors have reviewed the manuscript. All authors read and approved the final manuscript.

\section{Acknowledgements}

We will like to appreciate the Government of Ghana for providing funds for this study. We also thank Mr Prosper Segbefia and all the technicians of the Microbiology Laboratory in the Department of Pharmaceutics, KNUST for their assistance.

\section{Author details}

${ }^{1}$ Department of Pharmaceutics, Faculty of Pharmacy and Pharmaceutical Sciences, College of Health Sciences, Kwame Nkrumah University of Science and technology, Kumasi, Ghana. ${ }^{2}$ Department of Pharmacognosy, Faculty of Pharmacy and Pharmaceutical Sciences, College of Health Sciences, Kwame Nkrumah University of Science and technology, Kumasi, Ghana.

Received: 20 February 2012 Accepted: 27 September 2012 Published: 16 October 2012

\section{References}

1. Fenical W: Chemical studies of marine bacteria: developing a new resource. Chem Rev 1993, 93(5):1673-1683.

2. Singer RS, Finch R, Wegener HC, Bywater R, Walters J, Lipsitch M: Antibiotic resistance - the interplay between antibiotic use in animals and human beings. Lancet Infect Dis 2003, 3:47-51.

3. Bhavnani SM, Ballow CH: New agents for Gram-positive bacteria. Curr Op Microbiol 2000, 3:528-534.

4. Mincer TJ, Jensen PR, Kauffman CA, Fenical W: Widespread and persistent populations of a major new marine actinomycete taxon in ocean sediments. Appl Environ Microbiol 2002, 68(10):5005-5011. 
5. Radajewski S, Webster G, Reay DS, Morris SA, Ineson P, Nedwell DB, Prosser $\mathrm{Jl}$, Murrell JC: Identification of active methylotroph populations in an acidic forest soil by stable isotope probing. Microbiol 2002, 148:2331-2342

6. Prudhomme J, McDaniel E, Ponts N, Bertani S, Fenical W, Jensen P, Le Roch K: Marine Actinomycetes: a new source of compounds against the human malaria parasite. PLoS One 2008, 3(6):e2335. doi:10.1371/journal. pone.0002335.

7. Nostro A, Germanò M, D'Angelo V, Marino A, Cannatelli M: Extraction methods and bioautography for evaluation of medicinal plant antimicrobial activity. Lett Appl Microbio/ 2000, 30:379-384. doi:10.1046/ j.1472-765x.2000.00731.x.

8. Barrow Gl, Felthan RKA: Cowan and Steel's Manual for the Identification of Medical Bacteria. 3rd edition. Cambridge UK: Cambridge University Press; 2003:351-353.

9. Ivanova EP, Nicolau DV, Yumoto N, Taguchi T: Impact of conditions of cultivation and adsorption on antimicrobial activity of marine bacteria. Mar Biol 1998, 130:545-551.

10. Zheng $L$, Chen $H$, Han X, Lin W, Yan X: Antimicrobial screening and active compound isolation from marine bacterium NJ6-3-1 associated with the sponge Hymeniacidon perleve. World J Microbiol Biotechnol 2005, 21:201-206

11. Brandelli A, Cladera-Olivera F, Motta SA: Screening for antimicrobial activity among bacteria isolated from the Amazon Basin. Braz J Microbiol 2004, 35:307-310.

12. O'Brien A, Sharp R, Russell NJ, Roller S: Antarctic bacteria inhibit growth of food-borne microorganisms at low temperatures. FEMS Microbiol Ecol 2004, 48(2):157-167.

13. Ampofo AJ: A survey of microbial pollution of rural domestic water supply in Ghana. Int J Environ Heal Res 1997, 7(2):121-130.

14. Boadi KO, Kuitumen M: Urban waste pollution in the Korle Lagoon, Accra, Ghana. Environmentalist 2002, 22(4):301-309.

15. Katte $\mathrm{VY}$, Fonteh MF, Guemuh GN: Domestic water quality in urbancentres in Cameroon: a case study of Dschang in the West Province. African Water Journal 2003, 1:43-51.

16. Fianko JR, Osae S, Adomako D, Adotey DK, Serfo-Armah Y: Assessment of heavy metal pollution of the Iture Estuary in the Central region of Ghana. Environ Monit Assess 2007, 131(1-3):467-473.

17. Giudice AL, Bruni V, Michaud L: Characterization of Antarctic psychrotrophic bacteria with antibacterial activities against terrestrial microorganisms. J Basic Microbiol 2007, 47:496-505.

18. Bushell M, Grafe U: Bioactive metabolites from microorganisms. Industrial Microbiology 1989, 27:402-418.

19. Preetha RSJ, Prathapan S, Vijayan KK, Jayaprakash SN, Philip R, Singh BS: An inhibitory compound produced by Pseudomonas with effectiveness on Vibrio harveyi. Aquac Res 2009, 41:1452-1461.

20. Uzair B, Ahmed N, Kousar F, Edwards DH: Isolation and characterization of Pseudomonas strain that inhibit growth of indigenous and clinical isolates. The Internet Journal of Microbiology 2006, 2(2). Available at: http:// www.ispub.com/journal/the-internet-journal-of-microbiology.

21. Roitman J, Mahoney N, Janisiewicz W: Production and composition of phenylpyrrole metabolites produced by Pseudomonas cepacia. Appl Microbiol Biotechnol 1990, 34:381-386.

22. Price-Whelan A, Dietrich LEP, Newman DK: Rethinking secondary metabolism: Physiological roles for phenazine antibiotics. Nat Chem Biol 2006, 2:71-78

23. Sole M, Francia A, Rius N, Loren JG: The role of $\mathrm{pH}$ in the glucose effet on prodigiosin production by non-proliferating cells of Serratia marcescens. Lett Applied Microbiol 1997, 25:81-84.

24. Merrick MJ, Edwards RA: Nitrogen control in bacteria. Microbiol Rev 1995, 59:604-622.

25. Shapiro S: Nitrogen assimilation in Actinomycetes and the influence of nitrogen nutrition on Actinomycetes secondary metabolism. In Regulation of Secondary Metabolism in Actinomycetes. Edited by Shapiro S. Boca Raton, Florida: CRC Press; 1989:135-211.

26. Charyulu ME, Gnanamani A: Condition stabilization for Pseudomonas aeruginosa MTCC 5210 to yield high Titres of extra cellular antimicrobial secondary metabolite using response surface methodology. Current Research in Bacteriology 2010, 4:197-213.

27. Garland PB: Energy transduction in microbial systems. Symp Soc Gen Microbiol 1977, 27:1-21.
28. Riebeling $\mathrm{V}$, Thauer RK, Jungermann $\mathrm{K}$ : Internal-alkaline $\mathrm{pH}$ gradient, sensitive to uncoupler and ATPase inhibitor, in growing Clostridium pasteurianum. Eur J Biochem 1975, 55:445-453

29. Chang SC, Wei YH, Wei DL, Chen YY, Jong SC: Factors affecting the production of eremofortin C and PR toxin in Penicillium roqueforti. Appl Environ Microbiol 1991, 57:2581-2585.

30. Gibbons S: Plants as a source of bacterial resistance modulators and anti-infective agents. Phytochem Rev 2005, 4:63-78.

31. Annan K, Adu F, Gbedema SY: Friedelin: a bacterial resistance modulator from Paullinia pinnata L. J Sci Technol 2009, 29(1):152-159.

32. Pankey GA, Sabath LD: Clinical relevance of bacteriostatic versus bactericidal mechanisms of action in the treatment of Gram-positive bacterial infections. Clin Infect Dis 2004, 38(6):864-870.

33. Van Lagevelde P, Van Dissel JT, Meurs CJC, Renz J, Groeneveld PHP: Combination of flucloxacillin and gentamicin inhibits toxic shock syndrome toxin 1 production by Staphylococcus aureus in both logarithmic and stationary phases of growth. Antimicrob Agents Chemother 1997, 41:1682-1685

34. Russell NE, Pachorek RE: Clindamycin in the treatment of streptococcal and staphylococcal toxic shock syndromes. Ann Pharmacother 2000, 34(7-8):936-939.

doi:10.1186/1471-2180-12-234

Cite this article as: Tawiah et al:: Antibiotic producing microorganisms from River Wiwi, Lake Bosomtwe and the Gulf of Guinea at Doakor Sea Beach, Ghana. BMC Microbiology 2012 12:234.

\section{Submit your next manuscript to BioMed Central and take full advantage of:}

- Convenient online submission

- Thorough peer review

- No space constraints or color figure charges

- Immediate publication on acceptance

- Inclusion in PubMed, CAS, Scopus and Google Scholar

- Research which is freely available for redistribution

Submit your manuscript at www.biomedcentral.com/submit
C) BioMed Central 